Short Report

\title{
Consensus International Council for Commonality in Blood Banking Automation-International Society for Cell \& Gene Therapy statement on standard nomenclature abbreviations for the tissue of origin of mesenchymal stromal cells
}

\author{
Sowmya Viswanathan ${ }^{1,2,3,4, *}$, Rachele Ciccocioppo ${ }^{5}$, Jacques Galipeau ${ }^{6}$, Mauro Krampera ${ }^{7}$, \\ Katarina Le Blanc ${ }^{8}$, Ivan Martin ${ }^{9}$, Karen Moniz ${ }^{10}$, Jan Nolta ${ }^{11}$, Donald G. Phinney ${ }^{12}$, Yufang Shi ${ }^{13,14}$, \\ Zbigniew M. Szczepiorkowski ${ }^{15,16}$, Karin Tarte ${ }^{17}$, Daniel J. Weiss ${ }^{18}$, Paul Ashford ${ }^{10, * *}$ \\ ${ }^{1}$ Osteoarthritis Research Program, Division of Orthopedic Surgery, Schroeder Arthritis Institute, University Health Network, Toronto, Canada \\ ${ }^{2}$ Krembil Research Institute, University Health Network, Toronto, Canada \\ ${ }^{3}$ Institute of Biomedical Engineering, University of Toronto, Toronto, Canada \\ ${ }^{4}$ Department of Medicine, Division of Hematology, University of Toronto, Toronto, Canada \\ ${ }^{5}$ Department of Medicine, AOUI Policlinico GB Rossi \& University of Verona, Verona, Italy \\ ${ }^{6}$ Department of Medicine, University of Wisconsin Carbone Cancer Center, Madison, Wisconsin, USA \\ ${ }^{7}$ Department of Medicine, Section of Hematology, University of Verona, Verona, Italy \\ ${ }^{8}$ Division of Clinical Immunology and Transfusion Medicine, Karolinska Institutet, Stockholm, Sweden \\ ${ }^{9}$ Department of Biomedicine, University Hospital Basel, University of Basel, Basel, Switzerland \\ ${ }^{10}$ International Council for Commonality in Blood Banking Automation, Redlands, California, USA \\ ${ }^{11}$ Department of Internal Medicine, Stem Cell Program and Institute for Regenerative Cures, University of California Davis, Sacramento, California, USA \\ ${ }^{12}$ Department of Molecular Medicine, The Scripps Research Institute, Jupiter, Florida, USA \\ ${ }^{13}$ The First Affiliated Hospital, Soochow University Institutes for Translational Medicine, Suzhou, China \\ ${ }^{14}$ Institute of Health Sciences, Chinese Academy of Sciences, Shanghai, China \\ ${ }^{15}$ Pathology and Laboratory Medicine, Dartmouth-Hitchcock Medical Center, Lebanon, New Hampshire, USA \\ ${ }^{16}$ Institute of Hematology and Transfusion Medicine, Warsaw, Poland \\ ${ }^{17}$ UMR U1236-MICMAC, Immunology and Cell Therapy Lab, Rennes University Hospital, Rennes, France \\ ${ }^{18}$ University of Vermont College of Medicine, Burlington, Vermont, USA
}

\section{A R T I C L E I N F O}

\section{Article History:}

Received 13 April 2021

Accepted 20 April 2021

\section{Key Words:}

abbreviation

consensus statement

mesenchymal stromal cells

terminology

tissue source

\begin{abstract}
A B S T R A C T
The Cellular Therapy Coding and Labeling Advisory Group of the International Council for Commonality in Blood Banking Automation and the International Society for Cell \& Gene Therapy mesenchymal stromal cell (MSC) committee are providing specific recommendations on abbreviating tissue sources of culture-adapted MSCs. These recommendations include using abbreviations based on the ISBT 128 terminology model that specifies standard class names to distinguish cell types and tissue sources for culture-adapted MSCs. Thus, MSCs from bone marrow are MSC(M), MSCs from cord blood are MSC(CB), MSCs from adipose tissue are MSC(AT) and MSCs from Wharton's jelly are MSC(WJ). Additional recommendations include using these abbreviations through the full spectrum of pre-clinical, translational and clinical research for the development of culture-adapted MSC products. This does not apply to basic research focused on investigating the developmental origins, identity or functionalities of endogenous progenitor cells in different tissues. These recommendations will serve to harmonize nomenclature in describing research and development surrounding culture-adapted MSCs, many of which are destined for clinical and/or commercial translation. These recommendations will also serve to align research and development efforts on culture-adapted MSCs with other cell therapy products.
\end{abstract}

(c) 2021 International Society for Cell \& Gene Therapy. Published by Elsevier Inc. This is an open access article under the CC BY-NC-ND license (http://creativecommons.org/licenses/by-nc-nd/4.0/)

\footnotetext{
* Correspondence: Sowmya Viswanathan, PhD, Osteoarthritis Research Program, Division of Orthopedic Surgery, Schroeder Arthritis Institute, University Health Network, 60 Leonard Ave, Toronto M5T 0S8, Canada.

** Correspondence: Paul Ashford, MSc, International Council for Commonality in Blood Banking Automation, PO Box 11309, Redlands, California 92374, USA.

E-mail addresses: sowmya.viswanathan@uhnresearch.ca (S. Viswanathan), paul.ashford@iccbba.org (P. Ashford).
} 


\section{Introduction}

The need for standardization of terminology, coding and labeling for cellular therapy products was recognized early in the millennium, and a broad consensus has led to the international adoption of the ISBT 128 Standard. ISBT 128 terminology in particular is recognized beyond product labeling and has become the accepted standard for describing cell therapy (CT) products in documentation and publications. The mesenchymal stromal cell (MSC) committee at the International Society for Cell \& Gene Therapy (ISCT) has issued several position papers [1-4] describing minimal criteria to define MSCs, the use of matrix assays to functionally characterize MSCs and the use of the abbreviation "MSC" to denote culture-adapted MSCs in conjunction with an array of functional characterization readouts. Recognizing the importance of identifying the tissue source of MSCs and the need for a standardized approach to conveying this information, the ISCT MSC committee and the Cellular Therapy Coding and Labeling Advisory Group (CTCLAG) of the International Council for Commonality in Blood Banking Automation (ICCBBA) have collaborated to develop this recommendation.

\section{Background to ISBT 128 Terminology}

In 2005, the Foundation for the Accreditation of Cellular Therapy (FACT), the Joint Accreditation Committee of the ISCT and European Society for Blood and Marrow Transplantation (JACIE) and ICCBBA met to discuss how to achieve standardized terminology, coding and labeling of CT products. The organizations recognized the benefit of using ISBT 128 and proposed its adoption as the global standard for the labeling of CT products during the ISCT meeting (Vancouver, 2005). This proposal received strong support from meeting participants, and a decision was made to form an international steering committee with representation from major scientific and professional societies in the field of CT. ICCBBA established the CTCLAG with representation from AABB, the American Society for Transplantation and Cellular Therapy (formerly American Society for Blood and Marrow Transplantation), European Society for Blood and Marrow Transplantation, FACT, International Society of Blood Transfusion (ISBT), ISCT, JACIE, National Marrow Donor Program/Be the Match and World Marrow Donor Association.

The boards of all the participating organizations issued a joint statement, confirming support for the international use of ISBT 128 and tasking CTCLAG to (i) review existing regulation regarding labeling, (ii) design product label templates that satisfy regulatory requirements, (iii) provide a focus for the standardization of terminology and product naming, (iv) promote the adoption of the ISBT 128 standard in CT facilities around the world, (v) provide advice and support to facilities introducing the standard and (vi) advise on the ongoing development of the ISBT 128 standard to support new developments in CT.

CTCLAG developed standard terminology for CT products based on the ISBT 128 terminology model using classes and attributes. Class names were structured to identify the type of cell and the source; for example, hematopoietic progenitor cells, apheresis, or hematopoietic progenitor cells, cord blood. This terminology was published in 2007 concurrently in Bone Marrow Transplantation, Journal of Clinical Apheresis and Transfusion [5] and was subsequently incorporated into the ISBT 128 Standard Terminology. Since that time, CTCLAG has managed and updated the terminology to reflect changes in CT practice, and the most current version is maintained in the ISBT 128 Standard Terminology document, which is publicly available on the ICCBBA website (www.iccbba.org) [6].

It was noted that class names could be long and that there would be a need to abbreviate these in publications and procedures. The benefit of encouraging the use of a standard set of abbreviations was recognized, and in 2008 CTCLAG introduced a table of standard abbreviations into the terminology to identify the cell type and source. These abbreviations have been widely adopted and are recognized by AABB and FACT/JACIE. As the range of CT products has increased, the table of abbreviations has been expanded to accommodate new entries in a consistent manner.

The use of ISBT 128 for the coding and labeling of CT products is both widespread and growing. At the time of writing, there are 945 CT facilities in 65 countries registered to use ISBT 128.

ISBT 128 terminology is designed to provide generic product descriptions that can be used by different CT facilities to describe their products. Such generalization is widely used in the medical products of human origin field and facilitates effectiveness and biovigilance activities.

A distinct naming system is operated by the World Health Organization (International Nonproprietary Names [INN]) [7] and the American Pharmacists Association (United States Adopted Names [USAN]). INN and USAN are aligned and provide a non-proprietary name for a specific product manufactured by one manufacturer. The INN/USAN is a structured name designed to facilitate the identification of pharmaceutical substances or active pharmaceutical ingredients. The ISBT 128 labeling system is able to accommodate INN/USAN names, and manufacturers can request an ISBT 128 Product Description Code specific to their INN/USAN.

\section{The Development of Standard Terminology for MSCs}

The growing adoption of ISBT 128 coding and labeling practices mirrors the growing number of CT products that are approved in various jurisdictions [8], and this includes culture-adapted MSCs [9]. Culture-adapted MSCs from multiple tissue sources have received market authorization in different jurisdictions worldwide. For example, culture-adapted MSCs from adipose tissue have been approved for treatment of complex perianal fistulas in Crohn disease in Europe [10], culture-adapted MSCs from bone marrow have been approved for treatment of critical limb ischemia in Malaysia and India [11,12], culture-adapted MSCs from bone marrow have been approved for treatment of steroid-refractory acute graft-versus-host disease in pediatric patients in Canada and New Zealand [13,14] and in adult and pediatric patients in Japan [15], culture-adapted MSCs from bone marrow have been approved for treatment of spinal cord injury as part of a controversial conditional approval [16] and culture-adapted MSCs from umbilical cord blood have been approved for treatment of degenerative arthritis in South Korea [17].

The growing number of culture-adapted MSC products from various tissue sources underscores advances in basic science, an increasing understanding of MSC mechanisms of action and a mounting track record of clinical safety. However, the development of MSC products has also seen numerous setbacks as a field, including the recent Food and Drug Administration decision requiring additional clinical studies and functional characterization to approve Remestemcel-L (bone marrow-derived MSCs) for treatment of pediatric acute steroid-refractory graft-versus-host disease [18]. This decision highlights challenges in mechanistically understanding heterogeneity in MSC clinical responses compounded by differences in tissues of origin, donor heterogeneity and heterogeneity in host immune responses against a backdrop of complex pathologies. Heterogeneity in defining and functionally characterizing MSCs further confounds rigorous scientific efforts, as we lack even a basic consensus on common parlance and nomenclature terminology.

The position papers published by the ISCT MSC committee speak specifically to heterogeneous populations of culture-adapted MSCs, which are distinct transcriptomically and functionally [19] from purported in vivo counterparts. Culture-adapted MSCs are widely recognized for their potent immunomodulatory properties and the ability to stimulate repair of diseased or damaged tissues. Importantly, the tissue source of MSCs has repeatedly been shown to influence the 
functionality of MSCs [20-22], emphasizing the need to annotate the MSC abbreviations with their tissues of origin, as the authors previously recommended, while recognizing the controversy surrounding the use of "mesenchymal" in the abbreviations [4]. Indeed, there is growing evidence of the biological heterogeneity of MSCs based on tissue of origin, as evidenced by secretome [23], transcriptome [20], epigenome [24] and in vitro and in vivo functional analyses [25].

\section{Discussion}

In this article, the authors recommend a unified format for denoting the MSC abbreviations as well as tissues of origin following standard terminology developed by ICCBBA's CTCLAG. Specifically, the authors endorse the standard format to denote tissue of origin as a suffix using consensus-derived tissue abbreviations (Table 1). For example, under this standard terminology, MSCs derived from bone marrow would be abbreviated as MSC(M), MSCs derived from adipose tissue would be abbreviated as MSC(AT), MSCs derived from cord blood would be abbreviated as MSC(CB), MSCs derived from Wharton's jelly would be abbreviated as MSC(WJ) and MSCs derived from dental pulp would be abbreviated as MSC(DP). MSCs derived from bone marrow, adipose tissue, cord blood and Wharton's jelly are the most commonly investigated tissue sources under research and clinical investigation [26]. Abbreviations for other tissue sources are also recommended by ICCBBA's CTCLAG (Table 1) or will be developed using established consensus methods as newer sources of MSCs are tested and evaluated [27].

Although the use of ISBT 128 Standard Terminology standards remains in the purview of clinically used and/or approved products, the authors recommend the use of this standard terminology throughout the pre-clinical, translational and clinical research stages. This is particularly true as culture-adapted MSCs or their derivatives

Table 1

Recommended abbreviations for type of cell and source tissue.

\begin{tabular}{|c|c|c|}
\hline Type of cell & Source & Abbreviation \\
\hline Dendritic cells & Apheresis & $\mathrm{DC}(\mathrm{A})$ \\
\hline Dendritic cells & Cord blood & $\mathrm{DC}(\mathrm{CB})$ \\
\hline Dendritic cells & Marrow & $\mathrm{DC}(\mathrm{M})$ \\
\hline Dendritic cells & Whole blood & $\mathrm{DC}(\mathrm{WB})$ \\
\hline Hematopoietic progenitor cells & Apheresis & $\mathrm{HPC}(\mathrm{A})$ \\
\hline Hematopoietic progenitor cells & Cord blood & $\mathrm{HPC}(\mathrm{CB})$ \\
\hline Hematopoietic progenitor cells & Marrow & $\mathrm{HPC}(\mathrm{M})$ \\
\hline Hematopoietic progenitor cells & Whole blood & HPC(WB) \\
\hline Malignant cells & Apheresis & MALIG(A) \\
\hline Malignant cells & Marrow & MALIG(M) \\
\hline Malignant cells & Tumor & MALIG(TM) \\
\hline Malignant cells & Whole blood & MALIG(WB) \\
\hline Mononuclear cells & Apheresis & $\operatorname{MNC}(\mathrm{A})$ \\
\hline Mononuclear cells & Cord blood & $\mathrm{MNC}(\mathrm{CB})$ \\
\hline Mononuclear cells & Umbilical cord tissue & MNC(UCT) \\
\hline Mesenchymal stromal cells & Adipose tissue & MSC(AT) \\
\hline Mesenchymal stromal cells & Cord blood & $\operatorname{MSC}(\mathrm{CB})$ \\
\hline Mesenchymal stromal cells & Dental pulp & MSC(DP) \\
\hline Mesenchymal stromal cells & Marrow & $\operatorname{MSC}(\mathrm{M})$ \\
\hline Mesenchymal stromal cells & Wharton's jelly & MSC(WJ) \\
\hline Nucleated cells & Adipose tissue & $\mathrm{NC}(\mathrm{AT})$ \\
\hline Nucleated cells & Cord blood & $\mathrm{NC}(\mathrm{CB})$ \\
\hline Nucleated cells & Marrow & $\mathrm{NC}(\mathrm{M})$ \\
\hline Nucleated cells & Menstrual blood & $\mathrm{NC}(\mathrm{MB})$ \\
\hline Nucleated cells & Whole blood & $\mathrm{NC}(\mathrm{WB})$ \\
\hline Natural killer cells & Apheresis & NK(A) \\
\hline Natural killer cells & Cord blood & $\mathrm{NK}(\mathrm{CB})$ \\
\hline Natural killer cells & Marrow & $\mathrm{NK}(\mathrm{M})$ \\
\hline Natural killer cells & Whole blood & $\mathrm{NK}(\mathrm{WB})$ \\
\hline $\mathrm{T}$ cells & Apheresis & T CELLS(A) \\
\hline $\mathrm{T}$ cells & Cord blood & T CELLS(CB) \\
\hline $\mathrm{T}$ cells & Marrow & T CELLS(M) \\
\hline $\mathrm{T}$ cells & Tumor & T CELLS(TM) \\
\hline $\mathrm{T}$ cells & Whole blood & T CELLS(WB) \\
\hline
\end{tabular}

(including extracellular vesicles) [28] are investigated for their therapeutic properties. Consistency in nomenclature throughout the spectrum of research stages, particularly in the pre-clinical stage, will contribute to growing efforts to enable standardization and harmonization in defining and functionally characterizing MSCs from various tissues [29-32]. This MSC abbreviation recommendation is specifically directed to the clinical translational application of cultureadapted MSCs and is not intended to apply to basic research on the development/ontogeny of tissue-specific progenitor cells.

The authors recognize that the transition from the more commonly used prefix method to denoting culture-adapted MSCs with tissue of origin as a suffix-for example, MSC(M) versus BM-MSC, MSC(AT) versus AT-MSC, MSC(CB) versus UC-MSC-may take some getting used to. As the field of culture-adapted MSC products matures, with increasing market authorization approvals forecasted [33,34], this conversion to globally accepted standard terminology practices will align MSC products with other clinically used/approved CT products.

\section{Conclusions}

Focusing on standardized nomenclature is an important first step in enabling harmonization in a field that is exemplified by heterogeneity in the intrinsic biology of the cells as well as the methods and approaches to studying the cells. The authors therefore welcome this standardization of culture-adapted MSC nomenclature and see this as an important move in advancing MSC research, clinical translation and commercialization. ISCT and ICCBBA will continue to work with other scientific and professional societies to improve standardization in terminology.

\section{Funding}

No funding was received.

\section{Declaration of Competing Interest}

The authors have no commercial, proprietary or financial interest in the products or companies described in this article.

\section{Author Contributions}

Conception and design of the study SV, JG, IM, ZMS, PA, KM. Drafting or revising the manuscript: SV, RC, JG, MK, KL, IM, KM, JN, DGP, YS, ZMS, KT, DJW and PA. All authors have approved the final article.

\section{Acknowledgments}

The authors are current and active members of ISCT (SV, DP, MK, YS, DW, IM, KL, RC, AF and KT) and ICCBBA (PA, ZS and KM).

\section{References}

[1] Horwitz EM, Blanc KL, Dominici M, Mueller I, Slaper-Cortenbach I, Marini FC, et al Clarification of the nomenclature for MSC: The International Society for Cellular Therapy position statement. Cytotherapy 2005;7:393-5.

[2] Dominici M, Blanc KL, Mueller I, Slaper-Cortenbach I, Marini FC, Krause DS, et al. Minimal criteria for defining multipotent mesenchymal stromal cells. The International Society for Cellular Therapy position statement. Cytotherapy 2006;8:315-7

[3] Galipeau J, Krampera M, Barrett J, Dazzi F, Deans RJ, DeBruijn J, et al. International Society for Cellular Therapy perspective on immune functional assays for mesenchymal stromal cells as potency release criterion for advanced phase clinical trials. Cytotherapy 2016;18:151-9.

[4] Viswanathan S, Shi Y, Galipeau J, Krampera M, Leblanc K, Martin I, et al. Mesenchymal stem versus stromal cells: International Society for Cell \& Gene Therapy $\left(\right.$ ISCT $^{\circledast}$ ) Mesenchymal Stromal Cell committee position statement on nomenclature. Cytotherapy 2019;21:1019-24.

[5] Ashford P, Distler P, Gee A, Lankester A, Larsson S, Feller I, et al. Standards for the terminology and labeling of cellular therapy products. J Clin Apher 2007;22:249-57. 
[6] Rice B. Standard Terminology for Medical Products of Human Origin. San Bernardino, CA, USA: ICCBBA - ISBT 128 STANDARD; 2021.

[7] International Nonproprietary Names (INN). Nomenclature Scheme For Cell Therapy Products (CTP). Geneva, Switzerland: World Health Organization (WHO); 2015.

[8] Available Products. Alliance for Regenerative Medicine n.d. https://alliancerm. org/available-products/(accessed February 10, 2021)

[9] Galipeau J, Sensébé L. Mesenchymal stromal cells: clinical challenges and therapeutic opportunities. Cell Stem Cell 2018;22:824-33.

[10] European Medicines Agency. Alofisel. 2018. https://www.ema.europa.eu/en/medicines/human/EPAR/alofisel. (accessed February 10, 2021).

[11] Stempeutics Reserch Pvt Lts, Stempeucell, Stempeutron, Stempeucare, Cutisera Stem Cells n.d. https://www.stempeutics.com/clinical-trials-CLI.html. (accessed February 10, 2021)

[12] Gupta PK, Krishna M, Chullikana A, Desai S, Murugesan R, Dutta S, et al. Administration of Adult Human Bone Marrow-Derived, Cultured, Pooled, Allogeneic Mesenchymal Stromal Cells in Critical Limb Ischemia Due to Buerger's Disease: Phase II Study Report Suggests Clinical Efficacy. STEM CELLS Translational Medicine 2017;6:689-99.

[13] Government of Canada HC. Drug Product Database Online Query 2012. https:// health-products.canada.ca/dpd-bdpp/info.do?lang=en\&code=87195. (accessed February 10, 2021).

[14] Medsafe. Product Detail n.d. https://medsafe.govt.nz/regulatory/ProductDetail. asp?ID=15063. (accessed February 10, 2021).

[15] Products | JCR Pharmaceuticals Co., Ltd. n.d. https://www.jcrpharm.co.jp/en/site/ en/biopharmaceutical/product_tem.html. (accessed February 10, 2021).

[16] Cyranoski D. Japan's approval of stem-cell treatment for spinal-cord injury concerns scientists. Nature 2019;565:544-5.

[17] MEDIPOST. CARTISTEM ${ }^{\circledR}$. n.d. http://www.medi-post.com/cartistem/. (accessed February 10, 2021).

[18] Limited M. Mesoblast Receives Complete Response Letter From the FDA for Biologics License Application for Steroid-Refractory Acute Graft Versus Host Disease in Children. GlobeNewswire News Room 2020. http://www.globenewswire.com/news-release/ 2020/10/01/2102679/0/en/Mesoblast-Receives-Complete-Response-Letter-From-theFDA-for-Biologics-License-Application-for-Steroid-Refractory-Acute-Graft-VersusHost-Disease-in-Children.html. (accessed February 10, 2021).

[19] Nakahara F, Borger DK, Wei Q, Pinho S, Maryanovich M, Zahalka AH, et al. Engineering a haematopoietic stem cell niche by revitalizing mesenchymal stromal cells. Nat Cell Biol 2019;21:560-7.

[20] Ménard C, Dulong J, Roulois D, Hébraud B, Verdière L, Pangault C, et al. Integrated transcriptomic, phenotypic, and functional study reveals tissue-specific immune properties of mesenchymal stromal cells. Stem Cells 2020;38:146-59.

[21] Ringden O, Baygan A, Remberger M, Gustafsson B, Winiarski J, Khoein B, et al. Placenta-Derived Decidua Stromal Cells for Treatment of Severe Acute Graft-VersusHost Disease. Stem Cells Transl Med 2018;7:325-31.
[22] Jin HJ, Bae YK, Kim M, Kwon S-J, Jeon HB, Choi SJ, et al. Comparative analysis of human mesenchymal stem cells from bone marrow, adipose tissue, and umbilical cord blood as sources of cell therapy. Int J Mol Sci 2013;14:17986-8001.

[23] Kehl D, Generali M, Mallone A, Heller M, Uldry A-C, Cheng P, et al. Proteomic analysis of human mesenchymal stromal cell secretomes: a systematic comparison of the angiogenic potential. Npj Regenerative Medicine 2019;4:1-13.

[24] Ho Y-T, Shimbo T, Wijaya E, Ouchi Y, Takaki E, Yamamoto R, et al. Chromatin accessibility identifies diversity in mesenchymal stem cells from different tissue origins. Scientific Reports 2018;8:17765.

[25] Grégoire C, Ritacco C, Hannon M, Seidel L, Delens L, Belle L, et al. Comparison of Mesenchymal Stromal Cells From Different Origins for the Treatment of Graft-vs.Host-Disease in a Humanized Mouse Model. Front Immunol 2019;10:619.

[26] Moll G, Ankrum JA, Kamhieh-Milz J, Bieback K, Ringdén O, Volk H-D, et al, Intravascular Mesenchymal Stromal/Stem Cell Therapy Product Diversification: Time for New Clinical Guidelines. Trends Mol Med 2019;25:149-63.

[27] Bloor AJC, Patel A, Griffin JE, Gilleece MH, Radia R, Yeung DT, et al. Production, safety and efficacy of iPSC-derived mesenchymal stromal cells in acute steroidresistant graft versus host disease: a phase I, multicenter, open-label, dose-escalation study. Nature Medicine 2020;26:1720-5.

[28] Gowen A, Shahjin F, Chand S, Odegaard KE, Yelamanchili SV. Mesenchymal Stem Cell-Derived Extracellular Vesicles: Challenges in Clinical Applications. Front Cell Dev Biol 2020;8:149.

[29] ISO. ISO/WD TS 22859: Biotechnology-Biobanking-Requirements for human mesenchymal stromal cells derived from umbilical cord tissue. https://www.iso. org/cms/render/live/en/sites/isoorg/contents/data/standard/07/40/74052.html. (accessed February 10, 2021).

[30] ISO. ISO/CD 24651: Biotechnology-Biobanking-Requirements for human mesenchymal stromal cells derived from bone marrow. https://www.iso.org/cms/ render/live/en/sites/isoorg/contents/data/standard/07/91/79141.html. (accessed February 10, 2021)

[31] World Health Organization. WHO/BS/2019.2376 Collaborative Study to assess the suitability of the candidate WHO IRR for MSC identity (for flow cytometry) for advance therapies https://www.who.int/publications/m/item/WHO-BS2019.2376. (accessed February 10, 2021).

[32] Viswanathan S, Keating A, Deans R, Hematti P, Prockop D, Stroncek DF, et al. Soliciting Strategies for Developing Cell-Based Reference Materials to Advance Mesenchymal Stromal Cell Research and Clinical Translation. Stem Cells and Development 2014;23:1157-67.

[33] Mesoblast. Annual General Meeting November 24, 2020. http://investorsmedia. mesoblast.com/static-files/1f2a6a44-05ec-48a5-bcdf-ed244220e221. (accessed February 10, 2021)

[34] BioSpace. Athersys Preps MultiStem ${ }^{\circledR}$ Stroke Therapy for Approval Under Japan's RegenMed Law. https://www.biospace.com/article/athersys-preps-multistem-stroketherapy-for-approval-under-japan-s-regenmed-law-/. (accessed February 10, 2021). 